\title{
PNPRS NATIONAL CONFERENCE 2018
}

\author{
Philippine National Philosophical Research Society (PNPRS) \\ and \\ San Beda University \\ Theme: Identity, Values and Education
}

May 19, 2018

Multi Media Room, San Beda University

Mendiola, Manila

Conference Program

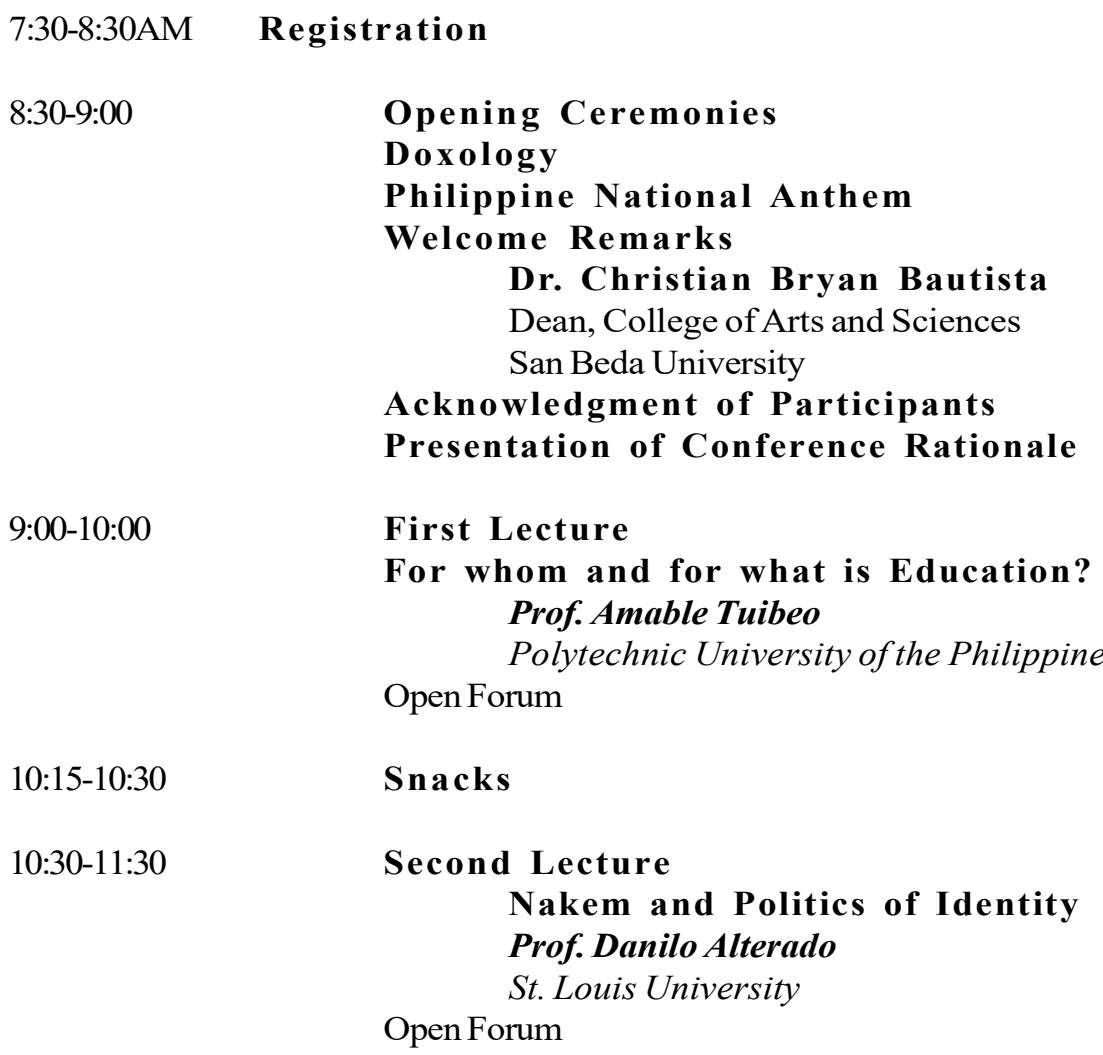




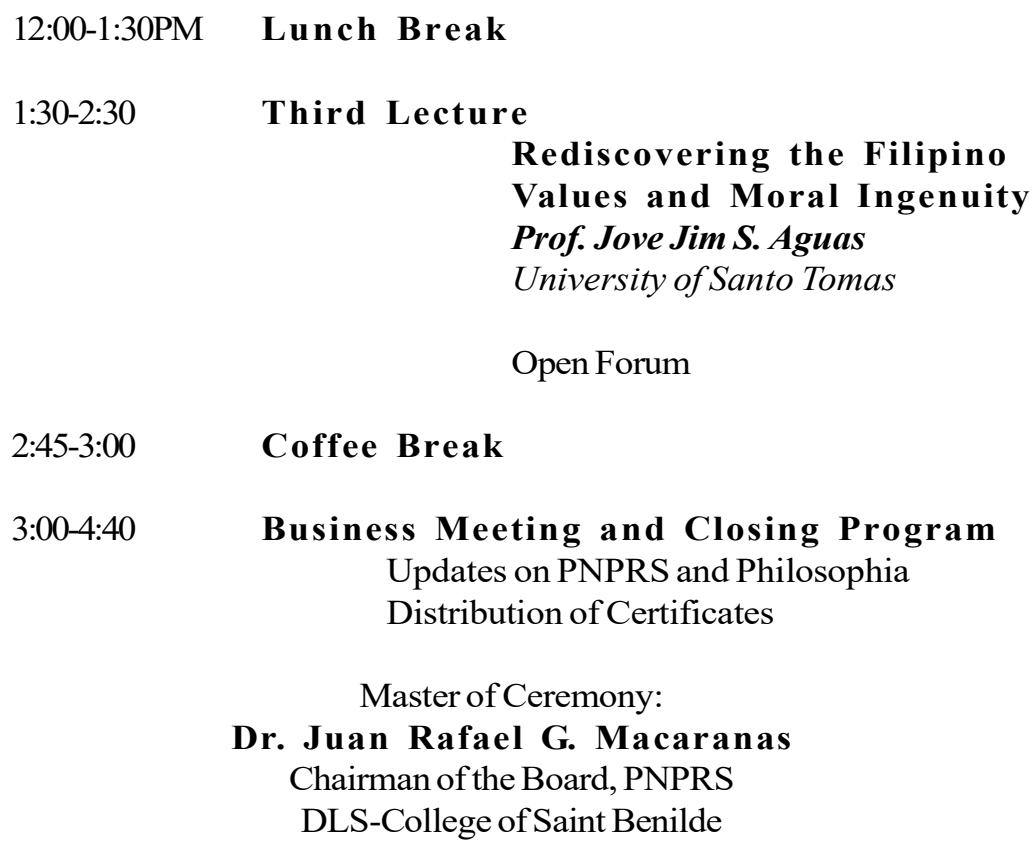




\title{
LECTURE SERIES 2018
}

\author{
Philippine National Philosophical Research Society (PNPRS) \\ in partnership with the \\ Polytechnic University of the Philippines
}

PNPRS Lecture Series 2018

Theme: Feminism and Education

October 27, 2018

CAL AVR, PUP Main Building

Polytechnic University of the Philippines, Manila

\section{Conference Program}

12:00-1:00 PM Registration

1:00-1:30 PM Opening Ceremonies

Doxology

Philippine National Anthem

Welcome Remarks Evangelina S. Seril, DEM

Dean, College of Arts and Letters

Polytechnic University of the Philippines

Opening Remarks, Rationale of the Lecture \&

Acknowledgment

Jeffrey L. Bartilet

Secretary, PNPRS

Co-convenor of the Lecture Series

1:30-2:30 PM First Lecture

"Extending Freedom: A Critique of bell hooks' Feminist Theory"

Hazel T. Biana, Ph.D

Associate Professor

Department of Philosophy

De La Salle University-Manila

2:30-2:45 PM Picture-taking and Snacks 
2:45-3:45 PM Second Lecture

"De-neoliberalizing subjects: A case for reaffirming gender-inclusivity in general education" Narcisa Paredes-Canilao, Ph.D. Professorial Lecturer in Philosophy Department of History and Philosophy University of the Philippines-Baguio

Open Forum

4:15-4:30 PM Awarding of Certificates

4:30-5:00 PM Announcements and Closing Message Jove Jim S. Aguas, Ph.D.

Masters of Ceremony

Juan Rafael G Macaranas, Ph.D. PNPRS Chairman of the Board

De La Salle-College of Saint Benilde
Fleurdeliz R. Altez-Albela, Ph.D. PNPRS Auditor University of Santo Tomas 